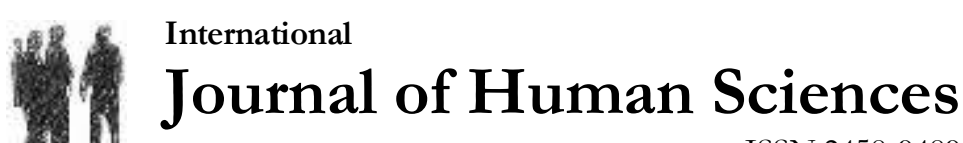 \\ ISSN:2458-9489
}

Volume 14 Issue 4 Year: 2017

\section{Discriminatory land use planning and flood risk management in Karonga Town, Malawi}

\author{
James Gondwe ${ }^{1}$ \\ Mtafu Manda ${ }^{2}$ \\ Dominic Kamlomo ${ }^{3}$
}

\begin{abstract}
This study examines how discriminatory land use planning predisposes the low income residents to flood disaster risks in Karonga town, Malawi. Using a qualitative research design, in-depth interviews were conducted with ten government and non government institutions engaged in land use planning and disaster risk management and traditional leaders. The study showed that theoretical aims of land use planning to improve the living environment remain partial and in certain cases exacerbate risks posed by floods because the planning tool divides the urban landscape into formal and informal spaces. Such separation which coincided with incomes levels forced the marginalised and urban poor to occupy flood-prone areas While literature on flood control promotes an integrated approach to flood risk management, land use planning practice is singled out as a regulatory measure which ironically not only fails to meet the needs, but also increases vulnerability to flood risks, of the urban poor residents. The study further revealed that land use planning has failed to reduce flood disaster risks in informal spaces because it is not compatible with the needs of the urban poor.
\end{abstract}

Keywords: Land use planning; risk reduction; urban poor; informal spaces.

\subsection{Introduction}

Karonga Town is a site of multiple natural hazards such as earthquakes, floods, droughts and strong winds as reported by the United Nations Human Settlements Programme (UNHABITAT, 2013). Flooding has a high recurrent frequency, approximately every 10 years (UNHABITAT, 2013). While scholarship indicates the importance of land use planning as tool for reducing flood risks and enhancing resilience against floods (Bloch, 2013, Sarah, 2015), it seems not much research has been done in Malawi to determine its efficacy in reducing flood risks. In addition, the bulk of knowledge being yielded on risks in Africa focuses more on large cities than on small and medium towns (Satterthwaite, 2016). Thus there is a need to generate data that should be used to enhance the capacity to act on flood risks of small towns in Sub-Saharan region such as Karonga Town. So far what has been done is a study on an assessment of the effectiveness of urban planning on reducing disasters (Manda, 2014). Although Manda (2014) provides an insight into how urban planning can lead to reduction of flood risks, the paper

\footnotetext{
${ }^{1}$ Faculty of Education, Department of Geography \& Earth Sciences, Mzuzu University, jamgondwe@yahoo.co.uk

${ }^{2}$ Faculty of Environmental Science, Planning Unit, Mzuzu University, mtafu.manda@gmail.com

${ }^{3}$ Faculty of Environmental Sciences, Department of Lands, Mzuzu University, dkamlomo@yahoo.com
} 

Karonga Town, Malawi. Journal of Human Sciences, 14(4), 3343-3355. doi:10.14687/jhs.v14i4.4706

focuses more on non structural measures, in particular planning and governance than on structural management, yet land use planning permeates both structural and non structural measures of disaster risk reduction. In particular, Manda's study did not discuss how the division of Karonga Town into formal and informal spaces by the planning framework has predisposed the low income people who cannot meet the demands and requirements of formal spaces. This paper, therefore, argues that while literature on flood control promotes an integrated approach to flood risk management, land use planning practice as a regulatory measure ironically increases vulnerability to flood risks of the socio-economically marginalised urban poor. In other words, there are some missing pieces within the land use planning strategies that bedevil the use of an integrated strategy of flood management that, according to Bloch (2013), requires the use of both non structural and structural measures.

In order to determine how land use planning condemns the marginalised and poor in urban areas to flood risk prone sites, the paper explores the following thematic issues; (a) planning measures that have been undertaken to reduce flood risks, (b) institutional arrangements in planning for floods (c) characteristics of locations frequently affected by floods, and (d) possible solutions to address flood risks. An analysis of the four thematic issues reveals reasons why land use planning has failed or indeed has limited capacity, to reduce flood risks in Karonga.

\subsection{Literature review}

\subsection{Land use planning and disaster risk management, an analytical framework}

Literature on urban floods indicates that there has been an increasing magnitude and frequency of floods in the past twenty years and the number of people affected by floods has increased (Amoako, 2016, and Jha, et al., (2012). Cities are being affected by urban flooding which according to Jha, et al., (2012) have financial and economic effects. Apart from financial implications, each succeeding flood event exposes the weaknesses of the existing flood prevention system which raises questions about the relevance and effectiveness of the means of prevention (Barroca, et al., 2006) Although some city governments have designed and implemented strategies and measures to reinforce resilience against floods, many urban dwellers remain predisposed to flood risks. Van Zyl, (2006) argues that the economic, population and environmental losses which are caused by natural or human made disasters require a systematic approach. Furthermore each flood incident generates new knowledge on how to cope with flood disasters (Liao, 2012). One of the approaches to the management of flood disasters is the pressure and release model (PAR) which posits that there is an inherent connection between a hazard and vulnerable population (Awal, 2015, Wisner et al, 2004). It is the vulnerability of the people that leads to the occurrence of the disaster. The model further states that vulnerability of the people to disaster is a result of multiple physical, social, economic, political and environmental causes (Kita 2013, Wanga 2012, Yasir 2009). Thus the PAR model is useful for this study because of two reasons. Firstly, because it is because land use planning cuts across environmental, social, economic and political causes of flood disasters (Kita, 2013). It is through the lens of the PAR model that one is able to discern the non structural and structural causes of flood disasters. Secondly, the model can be used to evaluate the effectiveness of the current measures being used to reduce or mitigate flooding and its impacts. While land use planning is a tool that is used to reduce flood risks (Bloch, 2013; Sarah, 2015; Manda, 2014), it can increase people's vulnerability to flood disaster risks especially in urban environments where informality is a visible landscape. It is through the lens of the PAR model that it is argued that vulnerability of the urban poor to flood risks is socially constructed. 
Gondwe, J., Manda, M., \& Kamlomo, D. (2017). Discriminatory land use planning and flood risk management in Karonga Town, Malawi. Journal of Human Sciences, 14(4), 3343-3355. doi:10.14687/jhs.v14i4.4706

\subsection{Land use planning as a tool for management of flood disaster risks}

Land use planning is a tool that can be used to permeate both structural and non structural methods of reducing flood risks. It regulates the physical space and guides the course of future activities as stipulated by guiding principles (Ran and Nedovic-Budic, 2016). The main merit of integrating land use planning with flood risk management is its appeal to different stakeholders (Roth, 2012, Zyl, 2006, Galderisi and Menoni, 2015). In fact multidisplinary and multi-sectoral approaches to flood risk management are fashionable where different stakeholders are involved. Furthermore land use planning has the potential to reduce people's exposure to hazardous environments (Galderisi and Menoni, 2015, Amoako, 2016) by allocating specific spaces for specific uses. However, land use planning as a tool for mitigating flood risks is limited and problematic. Although the potency of land use planning in mitigating flood risks is well recognized, its expediency is reduced by many obstacles (Ran and Nedovic-Budic, 2016). This study conceptualizes how land use planning as a tool of flood risk management predisposes the urban poor to flood risks. It further argues that although land use planning has the merit of permeating both structural and non structural measures, it has weaknesses that lead to recurrence and accumulation flood risks.

\subsubsection{Ordered space and vulnerability to flood disaster risks}

Research on urban development in developing countries has shown that land use planning frameworks have succumbed to the binary logic in which cities have been divided into formal and informal spaces (Eligu, 2011, Scholz, 2010, Varley, 2009, Jekins, 2004). The two cities are further conceptualized into 'blackness' and 'whiteness' metaphors. 'Whiteness' is associated with sanity and orderliness It is shaped by a concern with aestheticism (order, harmony, formality and symmetry) (Watson, 2009). It is the space that has flood resistant and resilient facilities. The metaphor 'blackness' is an antonym of whiteness' which means unplanned and unregulated activities that should be hidden from the public spaces therefore should be relegated to peripheral areas. 'Blackness' is associated with eviction, destruction and death (Yiftachel, 2009). It is taken as a malfunction of activities that take place outside the purview of the urban planning framework and most occupants of such spaces are susceptible to flood disaster risks. This study argues that it is the construction of the 'black spaces' by the land use planning framework that leads to the recurrence and accumulation of urban flood risks. 'Blackness' is a result of flawed government planning frameworks which lead to the growth of informal activities in unsafe urban environments (Ubale, et al., 2013). In addition, the state use irregular and fragmented regulations that increase time and cost for land developing (Marx, 2007). It should be noted that the state's planning machinery marginalises the urban poor who are the majority of most cities in developing countries. For example $68 \%$ of Malawi's urban landscape (Colenbrader, 2016) is occupied by informal housing, although informality should not be casually associated with poverty. Informal housing exposes the urban poor to urban disasters because substandard residential and other properties kill many people when they collapse (Ubale, etal., 2013). As such the state's 'convenient absence' (Amoako, 2016) is shown by a visible and deliberate neglect of informal settlements yet informal settlements do not have adequate physical infrastructure for reducing flood risks (Amoako, 2016) and social and economic facilities that enhance the urban poor's capacity to act against flood risks.

That land use planning is used as a tool for reducing flood risks has been well documented (Ran and Nedovic-Budic, 2016, Amoako, 2016, Collings, 2009 and WMO and GWP, 2007). However, land use planning has failed to break a vicious cycle of flood risks that continue to affect most cities in the global South. In fact the planning framework is not fully integrated into the flood risk management approach (Ran and Nedovic-Budic, 2016). Its emphasis on producing ordered spaces 
through the use of regulations has excluded the urban poor who cannot afford a luxurious life demanded by regulated spaces. The major reason for failing to reduce flood risks as argued by Dowall and Clark (1996), is that land use planning prescribes inflexible regulations that are not propoor particularly in developing countries. Pro poor plans for accommodating and safeguarding the wellbeing of the urban poor have not been effectively generated. The planning theory and practice has excluded the urban poor from participating in the formal land markets (Watson, 2009), increasing their vulnerability to flood risks. Thus the contemporary planning theory and practice continue to grapple with tensions between informality and the state's desire to produce safe and ordered urban environments. The tension is growing because the state has decided to continue using urban planning frameworks which according to Gencer (2013) are rigid and do not respond to the needs of the urban poor.

\subsection{Methodology and study location}

\subsection{Study site}

Karonga town is currently ranked fifth in the urban settlement hierarchy of Malawi. Categorised as a sub-regional centre, the town is a hub of decentralized urban governance where industry, commerce and services are expanding due its proximity to the border with Tanzania through which most of imports enter Malawi from the port of Dar es Sallam. However, Karonga is a town prone to all kinds of natural hazards including earthquakes and floods (Manda, 2014). For example, the town experienced the most serious flood disasters between 1979 and 1980 which damaged most of the old town. The town also experienced a series of earth tremors in 2009. Since 2009, flash floods and earthquakes have disrupted the socio-economic activities of the people of Karonga town, destroyed private and public infrastructures such as health, education and agriculture (GOM, 2010). Despite some measures to control floods, the Karonga Town's susceptibility to floods has increased (Figure 1). Karonga has experienced devastating floods and droughts since 1946 (Manda et al, 2016). Despite an increasing frequency and magnitude of flooding, the population continues to grow and settlements densify including within areas already known to have been affected before. The current study focuses on how land use planning has increased susceptibility of the urban poor to flood risks through its emphasis on dividing the town into formal and informal spaces. 


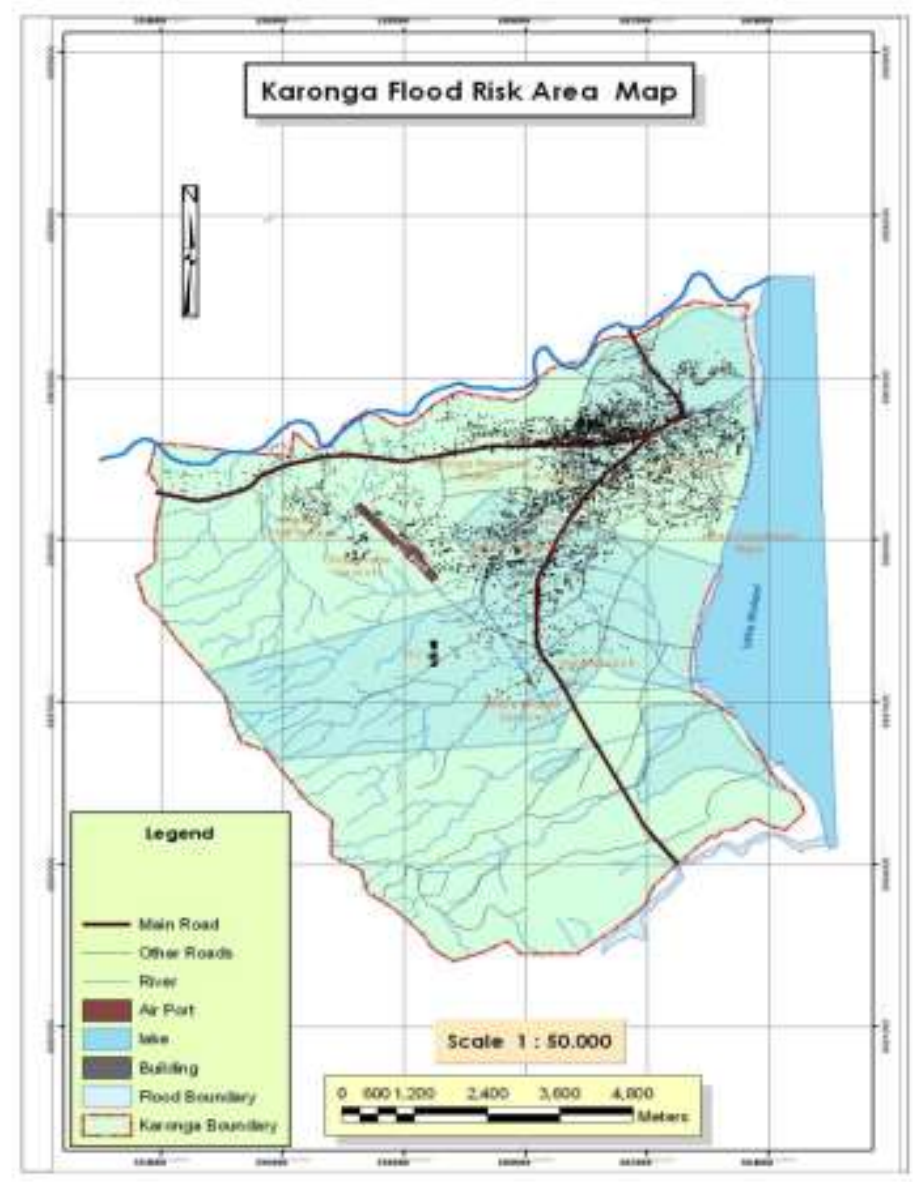

Figure 1: Karonga flood risk map (Source: GOM, 2013

\subsection{Study Design and Data Collection}

The paper used a qualitative research design to assess the effectiveness of land use planning in reducing flood risks and increasing resilience to floods in Karonga Town. The study examined different experiences, perceptions and perspectives of different stakeholders involved in flood risk management $\mathrm{s}$ in Karonga Town. Ten key informants were drawn from both state and nonstate originations were purposively sampled and interviewed using a semi-structured questionnaire. A total of seven informants from state organisations were consulted and three were drawn from the local chiefs who live in 'urban villages.' Key informant interviews were conducted so as to develop an understanding of how different stakeholders perceive the effectiveness of planning as a tool for reducing flood risks. Data interpretation and discussion took place concurrently so as to avoid repetition which helped to identify gaps between current and previous studies (Gondwe, 2013). The qualitative data was analysed manually by categorizing the data into core themes, recurrent patterns of events being narrated, perceptions and uniqueness of events. Relationships between or/and among the variables were discerned. In addition some official documents like the Karonga Disaster Contingency Plan and Karonga Urban Structure Plan were analysed for their relevance to the reduction of flood disaster risks. 

Karonga Town, Malawi. Journal of Human Sciences, 14(4), 3343-3355. doi:10.14687/jhs.v14i4.4706

\subsection{Results and Discussion}

\subsection{Characteristics of flood prone areas}

The study established that floods occurred in flat areas which have specific physical characteristics. It was noted that Karonga town experiences urban floods around the town centre because of clogged drainage infrastructure such that storm water around the town centre is not efficiently discharged to the main drainage channels. Field observations revealed that drainage network in Karonga town consists of very shallow and narrow channels which measure from a range of about $0.4 \mathrm{~m}$ in depth and $0.4 \mathrm{~m}$ in width to $1.5 \mathrm{~m}$ depth by $1.5 \mathrm{~m}$ width in some areas. The drainage network was blocked by solid wastes particularly around the town centre while in some places it was completely buried. Andjelkovic (2001) argues that blocked drainage and inlets cause surcharge that leads to flooding. The flood water from the town is either directed to nearby low income settlements of St Mary's or actually prevents these inhabitants from accessing their small scale businesses at the market located in the town centre. In this respect, lack of a functional drainage system affects the socio-economic day to day activities.

The study further established that $60 \%$ of informal houses were built on flood plains and that these were largely the homes of low income people. Human activities such as farming and housing construction are taking place on the dyke and artificial channels that were built to drain water to the lake. Manda (2014) observes that the artificial channels were occupied by low income people who used the land for housing construction and for rearing animals. Thus WMO and GWP (2007) argue that human activities which take place on the natural environment end up altering the dynamic equilibrium of the hydrologic cycle that trigger new processes during the rainfall period. Most of the houses as observed by Manda et al, (2016) are built of temporal materials such as grass thatch, mud floors and sun dried bricks that cannot stand a major flood event. The district physical planning officials link the flooding to illegal land markets. In the words of one Town council:

\section{"The flooding experience of Karonga is a result of Illegal land transactions which are made worse because planning followed the people."}

Simply put, the town boundary extended to the rural areas which became 'urban villages' when Karonga became a town in 1991 has always designated the area as settlement for the low income groups of Karonga. Houses which have been built and are still being built do not comply with the standards and building codes as demanded by the local government and owing to their low quality could claim many lives upon collapsing (Ubale and Martin 2013). The local government officials appear to renegade on their role by arguing that the customary tenure system was to blame for the low income people settling in flood risk sites. As stated by the planning official:

\section{"Chiefs sell land and sometimes redistribute it freely to their subjects and that land is part of floodplain."}

However, chiefs argued that there was nothing wrong to distribute land to the landless subjects except that the local government had failed to install flood resistant infrastructure after extending the town's boundary to their spaces. The town's boundary was extended without renovating the physical structures such as houses and infrastructure that would reduce the residents' exposure to flood risks. 
Gondwe, J., Manda, M., \& Kamlomo, D. (2017). Discriminatory land use planning and flood risk management in Karonga Town, Malawi. Journal of Human Sciences, 14(4), 3343-3355. doi:10.14687/jhs.v14i4.4706

\subsection{Land use planning measures for flood risks reduction in Karonga Town}

\subsubsection{Relocation to upland sites}

The study established that several land use planning measures have been implemented in the past in Karonga Town. Respondents stated that relocation of residential, commercial and industrial activities to the upland areas which were declared to be free from flood risks was high on the agenda. Relocation of the old town center to the current location had started in 1980s when the old town site experienced floods due to an increase in water level from $471 \mathrm{~m}$ above Karonga reference level in 1915 to 477.8m on Lake Malawi (Manda, et al 2016). Most of the commercial activities have since shifted to sites considered safe such the current site and a new site for residential use has been identified in Bwiba, which is an upland site. Commercial banks, market stalls, shops and houses have been abandoned in favour of the current site which was perceived to be secured from floods. Relocation is taken as the best option of reducing vulnerability to risk of floods (Mulyani, et al, (2014).

However, the relocation approach has been faulted on three reasons. The first reason is risk communication, interactive process where individuals, groups and institutions exchange information (Bouchard, et al, 2007), failed to inculcate a positive response from the low income people especially those who live in informal settlements. Community leaders of various local structures such as Neighbourhood Disaster and Risk Management Committee (NDRMC) and the Village Development Committee (VDC) argued in FGDs that the issue of relocation to upland sites was an example of a failed collaborative planning practice. Leaders of NDRMC and VDC complained that they were not properly consulted on the issue of relocating to new sites. When sites for relocation were chosen, such as at Bwiba, there was lack of consultation with the supposed beneficiaries.

Unidirectional consultation strategies fail to accommodate local knowledge and community needs and reduce effectiveness of design and implementation of flood risk management (Mulyani, etal., 2004). Lack of collaborative approach mechanism forced some traditional leaders to perceive themselves as occupying rural spaces because they argued that they are not consulted in many of the major planning activities of the town. They argued that local government had not effectively engaged them on the debate to relocate to upland sites. Thus the planning practice is still trapped in the 'rational paradigm' (Watson, 2003) which is dominated by the top down approach which exposes the local people to flood risks.

The other reason is the land use planning regime has failed to accommodate the cultural socioeconomic diversity which is deeply entrenched on Karonga's urban landscape. The designing and implementation of sites and serviced plot schemes was based on preconceived notion that all people in Karonga Town had the capacity to occupy serviced plots yet the 'urban divide' that resembles colonial and post colonial geographies is visible in Karonga Town. Karonga Town is a has a mixture of the low income, middle income and affluent class. The low income who are the majority $(60 \%)$, live in 'urban villages' which were constructed on the floodplain. On the other hand the middle income and affluent, who are the minority $(40 \%)$, live in planned areas like Bwiba which are far away from the floodplain. Literature on the accessibility of formal land markets by the urban poor show that most of the urban poor are marginalised (Marx, 2007, Twarabamenye and Nyandwi. 2012, Oloyede, et al 2012). The Chief of Mwahimba urban village stated that the urban poor cannot afford the serviced plots and the procedures for accessing serviced plots are long and intimidating. From the traditional leader's point of view it not far from concluding that the planning regime has led to the creation of socially segregated urban development that expose the low income people to hazard exposed areas, which lack disaster 
Gondwe, J., Manda, M., \& Kamlomo, D. (2017). Discriminatory land use planning and flood risk management in Karonga Town, Malawi. Journal of Human Sciences, 14(4), 3343-3355. doi:10.14687/jhs.v14i4.4706

resistant infrastructure (UNISDR 2015). Such exclusionary geographies have compelled the urban poor to actively participate in informal housing estates in areas such as Mwahimba village which were built on the floodplain. Such places predispose the residents of Mwahimba village to flood disaster risks.

Lastly, the planning theory and practice is caught up in a conflict of rationalities, the rationality to shift people to upland sites which are safe from floods and the rationality to encourage people to remain in the flood plain through the provision of piecemeal solutions. Watson (2003) argues that a clash of rationalities take place when a plan or development project has different aims from what the occupants think or are doing For example, while places like Mwahimba Village have been declared as flood prone sites, the local people prefer to live there because of the rich soils for rice cultivation. Contradictions merge when the same officials are seen to locate development projects within the same sites declared unsafe. For example, a primary school was recently constructed in the area. Implicit in the school project is the signal that relocation to upland sites is an illusion that will never be practical and real. The school project which was suggested by the indigenes and supported by local government is a way of defeating the earlier narrative of relocation to safer places. The chiefs and their subjects are also against the narrative of relocating to upper regions because they are afraid of uprooting livelihood strategies and outcomes that are supported by their proximity location to the lake. As such the school project which is not yet fitted with flood disaster risks resistant facilities will perpetuate indigenous people's vulnerability to flood disaster risks.

\subsubsection{Development and implementation of flood risk reduction plan}

Karonga Town Council has a detailed Disaster Contingency Plan which stipulates how disasters like floods, strong wind, earthquake and others can be reduced and controlled (GOM, 2013). This study also established that flood prone areas have been delineated and hazard maps for flood prone areas have been drawn. Different hazard zones are delineated on the hazard maps and land use regulations are also implemented to control the flood damage (WMO and GWP 2007). Hazard maps are used for the spatial planning of flood risks. Although the Disaster Contingency Plan is an indicator of a shift in disaster management paradigm from the reactionary to the proactive models, it should be noted that parameters like rural-urban interactions were not thoughtfully considered. The proactive model of flood risk reduction designed by the Karonga Town Council does not perceive rural and urban spaces as a web of environmental and socioeconomic interaction but as fixed and binary spaces. There is vast literature that indicates that rural and urban spaces are increasingly becoming linked (Steinberg 2014). Environmental and socio-economic flows take place between rural and urban spaces. Thus the urban spatial bias in Karonga Town has exposed recent migrants who occupied informal settlements sto be vulnerable to flood risks. Recent rural-urban migrants easily occupy informal settlements because these are the places that meet their financial capacity (Kita, 2017). The Disaster Contingency Plan did not consider designing control measures that operate in and outside the Karonga Town boundary. Land use planning has failed to straddle the rural-urban boundaries that lead to the development piecemeal solutions that predispose the low income people to flood risks.

\subsection{Institutional arrangements in planning for flood disaster reduction}

\subsubsection{Stakeholders in flood disaster reduction}

The study found that while there are different state and non state actors working tirelessly to reduce flood risks, sectoral approach to the reduction of flood risks is very visible. Organizations like Northern Region Water Board (NRWB) ensure that clean water is supplied to all residents of 
Gondwe, J., Manda, M., \& Kamlomo, D. (2017). Discriminatory land use planning and flood risk management in Karonga Town, Malawi. Journal of Human Sciences, 14(4), 3343-3355. doi:10.14687/jhs.v14i4.4706

Karonga Town. However, the supply water to informal settlements is a conflict of interest between the NRWB and the Department of Physical Planning. While the organizational structures have embraced the proactive strategies, which according to Gencer (2013) contribute to saving lives and property and resources, it is argued that organisations like Karonga Water Board and Physical Planning Department have contradictory approaches of reducing flood disaster risks. It was observed that the Karonga NRWB provides water services to informal settlements which the Physical Planning Department demarcates as illegal and unplanned. Water supply is taking place in informal settlements that have been built on the flood plain. The provision of water services to unplanned plots has encouraged low income people to occupy some peripheral areas which are susceptible to floods. Although this is a complex issue, on the surface the problem has been aggravated by the Department of Physical Planning. It should be noted that in Malawi the planning framework consists of different actors whose main role is to provide services and infrastructure to urban centers. At the center of different actors lies the Department of Physical Planning that produces plans for public land. Furthermore the inabilities of land use planning to cope with rapid population growth force migrants to locate in hazard susceptible informal locations (UNDP 2004).

\subsubsection{Institutional framework for development control and disaster reduction}

Karonga Town has a legislative framework for disaster risk reduction. The government in has developed building guidelines hazard prone areas. Adedeji, et al., (2012) argue that prevention is better and cheaper in disaster management because cure is expensive. Although physical planning, construction and building codes are part of the preventive package for disaster management (Gencer, 2013), their implementation has not yet yielded significant results. Low income communities who reside in flood prone locations of Karonga have failed to comply with building codes. The traditional leader of the village argued that most low income people cannot afford to build houses following the building codes demanded by the Department of Physical Planning. The cost of building materials is beyond their financial capacity. Dowal et al (1996) argue that land use planning regulations are too rigid and that such regulations do not favour lowincome communities in developing countries. In addition the guidelines seem to purport as argued by Twarabamenye et al., (2012) 'preconceived notions of an 'ordered' space which may not be compatible with land uses commonly associated with the poor." Thus the inability of land use planning to produce building codes that are compatible with social, culture and economic standards of the low income communities has not only exposed them to flood risks but also to the accumulation of flood risks.

\subsection{Possible solutions to management of flood risks}

\subsubsection{Upgrading of existing informal settlements}

The research study also attempted to find out from the stakeholders possible solutions to the problem of flooding in the study area. One major outcome from the views of respondents was the need to upgrade existing informal settlements. Leaders of the VDC suggested that all informal settlements which are located on the flood prone areas should be fitted with flood resistant and resilience infrastructure. The UNDP (2004) argues that there is a shift in management of flood risks from relocation to upgrading approaches that are part of the integrated flood management model. Thus, upgrading of the existing settlements will keep social, political, economic and cultural assets intact (Sofaniadi and Anggraeni, 2015). However the notes that the problem of settlement upgrading is the binary treatment of the informal/formal settlements by the planning regime. The binary depicts the informal as undesirable, illegal and peripheral and formal as a center, desirable and legal. Yet the formal 'sweeps the poor away' from linking with the formal because the standards that are set by the formal delink the poor from the 

Karonga Town, Malawi. Journal of Human Sciences, 14(4), 3343-3355. doi:10.14687/jhs.v14i4.4706

formal. The informal or the margins are spatially and socially marginalised (Watson, 2009; Govinda 2013). Their houses, identities and governmentalities are perceived as peripheral and unacceptable to the 'ordered space' that is being promulgated by urban planners in Karonga Town. Thus the proposed upgrading of informal settlement as a way of installing flood resistant and resilience infrastructure should be cautiously executed because the communities may also resist it if their needs are not accommodated. Perhaps there is need to take the middle way path between formality and informality (Varley 2009) or what Floridi et al (2016) perceive as the borderland between formality and informality. Using the middle way path or the borderland between formality and informality thesis, the upgrading framework should not really aim at creating an 'ordered space' which residents should strictly adhere to it but lead to the installation of facilities that as argued by Oloyede et al (2011) suit the social, economic and cultural standards of the location. Before the settlement upgrading scheme takes off the theory and practice of urban planning should thrive to mould a 'proper' community (Watson 2003) which is on the borderland of formality and informal.

\subsubsection{Strengthening the flood control embankment}

Several proposals were made by stakeholders on reducing flooding in the town. For example, it was suggested that the dyke which was constructed after the 1979-1980 floods (Manda 2014) was no longer an effective tool for controlling floods because of encroachment of human activities such grazing animals inside the dyke and also individual house developers who have encroached into the path of flood water between the dyke and the river. However the hydraulic performance of the dyke depends on two factors. The first factor is the earthen dyke is not an effective regulator of floods because it is an earthen dyke which is vulnerable to erosion and percolation of water.(Hossain and Sakai 2008). Thus there is need to replace the current earth dyke with a concrete dyke. Although the cost of constructing the concrete dyke is higher than that of the earth dyke, it is cheaper than the earth dyke on a long time basis because it does not require constant repair and reconstruction (Hossain and Sakai 2008). The second factor is when repairing or reconstructing the dyke, both non structural issues such the socio-economic conditions of the surrounding communities and structural factors such as the hydraulic performance of the dyke are considered. Thus, Hossain and Sakai, (2008) argue that the concrete embankment has a smaller space than the earthen embankment that provides more space for the flow of water from the river. In addition the concrete embankment is likely to reduce encroachment by animals and people because its floor is covered by concrete which prevents vegetation from growing.

\subsection{Conclusion}

The Karonga local government has attempted to design and implement planning measures to reduce flood risks. However land use planning as a tool for reducing flood risk has not produced the expected results. It has failed to protect the urban poor or to provide sites for housing in the safe upland at prices they can afford. In addition, although the land use planning framework which is used in Karonga Town consists of different actors, their approach to flood management is fragmented. The fragmentation of the planning framework is a result of land use planning that has failed to enhance integration in management of floods. While the suggestion to upgrade the settlements which are on the floodplain is a favourable approach among the indigenes who argue that their livelihoods and other assets will be left intact, it requires external resources and collaboration with the inhabitants themselves.. Informal settlements can become flood resistant if appropriate infrastructure is fitted. It is suggested that land use planning can become an effective tool for reducing flood risks if it accommodates the cultural, social and financial contexts needs of the urban poor.. However such an activity requires reorientation of the existing planning 
Gondwe, J., Manda, M., \& Kamlomo, D. (2017). Discriminatory land use planning and flood risk management in Karonga Town, Malawi. Journal of Human Sciences, 14(4), 3343-3355. doi:10.14687/jhs.v14i4.4706

framework so that the needs of the urban poor should be at the centre of the theory and practice of land use planning.

\subsection{References}

Adedeji, O.A., Odufuwa, B.O., \& Adebayo, O. (2012). Building Capabilities for Flood Disaster and Hazard Preparedness and Risk Reduction in Nigeria: Need for Spatial Planning and Land Management. Journal of Sustainable Development in Africa. Vol,14, No,1, pp1-58

Andjelkovic, I., (2001). Guidelines on structural measures in urban flood management, IHP Technical Documents in Hydrology, No 50. pp. 1-87, UNESCO, Paris. unesdoc.unesco.org/images/0012/001240/124004e.pdf

Amoako, C. (2016). Brutal presence or convenient absence. The role of the state in politics of flooding in informal Accra, Ghana. Geoforum 77. Pp 5-16. http://journals.sagepub.com/doi/abs/10.1177/0042098016686526

Australian Government, (2009). What is a Flood? Applying Geoscience to Australia's most Important Challenges, Sydney.

Awal, M.A (2015). Vulnerability to Disaster: Pressure and Release Model for climate change hazards in bangladesh. International Journal of Enviornmental Moniotirng and Protection Vo. 2 No. 2 pp.15-21

Barrientos, G.H. E. (2014). Institutional Aspects of Integrated Flood Management in Guatemala, Uppsala University.

Barroca, B., Bernardara, P., Mouchel, JM., Hubert, G. (2006). Indicators of urban flooding vulnerability, Natural Hazards and Earth System Sciences, Copemicus.

Bloch, R., (2013). Integrating Flood Risk Management and Land use Planning. ICLEI FORUM, Bonn

Bouchard, B., Goncalo, A., Susienk., M and Wilson K. (2007). Improving Flood Risk Management in Informal Settlements of Cape Town. An Interactive Qualifying Project Submitted to the Faculty of Worcester Polytechnic Institute in partial fulfillment of requirements of the degree of Bachelor of Science.

Chan, N. W., (1997). Institutional Arrangements for Flood Hazards in Malaysia: An Evaluation Using the Criteria Approach. Disasters, Vol. 21, No 3: pp.206-222. doi:10.1111/14677717.00057

Cissé O., Moustapha S, M., (2016). Flooding in the suburbs of Dakar: impacts on the assets and adaptation strategies of households or communities, Environment and Urbanisation, Vol. 28: No.1. pp.183-204. DOI: 10.1177/0956247815613693. www.sagepublications.com

Colenbrander, S.,(2016). Cities as engines of economic growth. The case for providing basic infrastructure and services in urban areas. IIED Working Paper, IIED,London

Collins A. E., (2009). Disaster and Development, Abington, Routledge.

Creswell, W.J. (2003). Research Design. Qualitative, Quantitative and Mixed Methods Approaches $\left(2^{\text {nd }}\right.$ Edition). Sage Publications, New Delhi

Dowall D. E., and Clark, G., (1996). Urban Management and Land, A framework for reforming urban land policies in developing countries. Urban management programme, policy paper series; UMPP no. 7. Washington, D.C. : The World Bank., pp.8-48.

Eligu, A.G. (2011) Coupling informality with formality: Ideas for innovative housing and urban development strategy. $4^{\text {th }}$ European Conference on African Studies.

Floridi, A., Wagner, N., and Cameron J. (2016) A study of Egyptian and Palestine trans-formal firms. A neglected category operating in the borderland between informality and formality.

Galderisi, A \& Menoni, S .(2015) Improving the role of land use planning for reducing existing and future risks. The "state of DRR at local level". A 2015 report on patterns of disaster risk reduction actions at local level.International Institute of Social Studies. ISS Working paper series/General series, Vol. 619, pp. 1-25 
Gondwe, J., Manda, M., \& Kamlomo, D. (2017). Discriminatory land use planning and flood risk management in Karonga Town, Malawi. Journal of Human Sciences, 14(4), 3343-3355. doi:10.14687/jhs.v14i4.4706

Gencer, E.A (2013). The interplay between urban development, vulnerability and risk management. A case study of the Istanbul Metropolitan Area. Springer Briefs in Environment, Security, Development and Peace.

Government of Malawi, (2013). Karonga Disaster Contingency Plan, Lilongwe.

Government of Malawi, (2013). Karonga Urban Structure Plan, Lilongwe.

Govinda, R. (2013).Introduction: Delhi’s Margins: Negotiating Changing Spaces and Governmentalities, South Asia Multi Disciplinary Academic Journal, Issue No.. 8

Gondwe, J \& Ayenabgo, K., (2013). Negotiating for livelihoods beyond the formal Mzuzu City, Malawi, by the urban poor: Informal settlements as spaces of income generating activities. International Journal of Human Sciences. Vol 10, No.1, pp.356-375.10.14687

Gupta, A.K \& Nair, S.S. (2011). Flood risk context of land-uses: Chennai city case, Journal of Geography and Regional Planning, Vol. 3, No.12, pp.365-372, New Delhi

Hossain, M.Z \& Sakai, T. (2008). Severity of Flood Embankments in Bangladesh and its remedial Approach. Agricultural Engineering International: the CIGR Ejournal. Manuscript Lw 08 004. Volume X.

Idris, S. \& Dharmasiri, M. (2015). Flood risk inevitability and flood risk management in urban areas: A review, Journal of geography and Regional Planning, Vol. 8, No.8. 10.5897/JGRP2015.0510

Institution of Mechanical Engineers. (2013). 'Natural disasters: saving lives today, building resilience for tomorrow', Westminster, London

Jenkins, P.(2004). Beyond the formal/informal dichotomy: Access to land in Maputo, Mozambique in Hansen, K.T and Vaa, M.(eds).,Reconsidering informality. Perspectives from Urban Africa. Nordiska Afrikain institutet, Stockholm

Jha, A. K., Bloch, R.,\& Lamond, J. (2012) Cities and Flooding: A Guide to Integrated Urban Flood Risk Management for the $21^{\text {st }}$ Century, World Bank. Vol. 1 No. 1, pp. 596-608.

Kita, M.S .(2017). Urban vulnerability, disaster risk reduction and resettlement in Mzuzu City, Malawi. International Journal of Disaster Risk Reduction Vol. 22 pp 158-166.

Kryspin-Watson J. (2016). Conference presentation on: Understanding Urban Flood Risk Management in East Asia and the Pacific, Tokyo.

Manda, M.A.Z. (2014). 'Where there is no local government: addressing disaster risk reduction in a small town in Malawi,' Environment \& Urbanisation, Vol. 26, No.2, pp.586-599.

Liao, K. (2012). A theory on urban resilience to floods-a basis for alternative planning practices. Ecology and Society 17(4):48 http://dx.org/105751/ES-05231-170448

Manda, M, Kamlomo, D., Mphande, C., Wanda, E., Msiska, O., Kaunda., J \& Kushe, J. (2016). Karonga Town: Growth and Risk Profile. Urban ARK Working paper no. 9, IIED, London.

Manuta, J., Khrutmuang, S., Huaisai, D \& Lebel, L. (2005). Institutionalized incapacities: the politics of re-distributing risks and altering vulnerbalities to floods in Thailand. USER Working Paper (http://www.sea-user.org)

Marx, C. (2007). Do Informal Land Markets Work for Poor People? An Assessment of three metropolitan cities in South Africa. Isandra Institute.

Mhonda A. (2013). Evaluating flash flood risk reduction strategies in built-up environment in Kampala, Enschede, The Netherlands.

Mulyani, S.T., Mellini., S \& Connie, S .(2014) .Community engagement for disaster resilience: flood risk management in Jarta, Indonesia in ANDROID Residential Doctoral School and the $4^{\text {th }}$ International Conference on Building Resilience, 8-11 September 2014, Salford United Kingdom

Oleyede, S.A., Emeka, I \& Ayedu, C.A .(2011). Informal Land Market: Alternative approach to mass residential housing provision in South Western Nigeria. Journal of Geography and Regional Planning Vol. 4, No. 11. pp 598-603 http://www.academicjournals.org/JGRP 
Gondwe, J., Manda, M., \& Kamlomo, D. (2017). Discriminatory land use planning and flood risk management in Karonga Town, Malawi. Journal of Human Sciences, 14(4), 3343-3355. doi:10.14687/jhs.v14i4.4706

Price., R.K \&Vojinovic, Z. (2008). Urban flood disaster management. Urban water Journal. 5;3 pp $259-276$

Ran, J., \& Nedovic-Budic, Z. (2016).Integrating spatial planning and flood risk management. A new conceptual framework spatially integrating policy infrastructure. Computers, Environment and urban Systems, Vol. 57. pp. 68-79.

Riley, D. (2012) .The political economy of urban food security in Blantyre, Malawi. The African Institute Occasional Paper series, University of Western Ontario Vol, 1, No.2, pp 1-6.

Roth, A.S. (2011). Challenges to disaster risk reduction. A study of stakeholder' perspectives in Imamo Yethu, South Africa. Report number 5358

Rumbach, A. (2016) .Decentralisation and small cities. Towards more effective urban disaster governance? Habital International. Volume 52 pp 35-42

Safrinal., S \& Sofaniadi,M . (2015). Should we stay or should we go? Understanding household decision making in climate change-affected areas of Indonesia. Policy Brief. Iied, London

Salkin, P. E., (2005). Effective Disaster Mitigation Depends Upon Well Coordinated Local Land Use Planning and Zoning. Real Estate Law Journal,Vol. 34 No. 108, 108-124.

Sarah, A. (2015) . Urban Flood Response Planning: Building Urban Resilience in Calgary and Toronto. Paper 1774 .

Satterthwaite, D.(2016) .Background Paper: Small ad intermediate urban centres in sub-Saharan Africa. Urban ARK Working Paper No 6,IIED,London.

Scholz, W.(2010) . Regulating informality-the influence of planning standards on long term sustainability of settlements. The case of Dar es Salam/Tanzania A-AERUS. Urban knowledge in cities of the South.

Steinberg, F.(2014). Rural-Urban Linkages: An Urban Perspective. RIMISP working paper.

Twarabamenye, E \& Nyandwi E. (2012). Understanding Informal Urban Land Markets Functioning in Peri-urban Areas of Secondary Towns of Rwanda: case study of Tumba Sector, Buture, Rwanda Journal of Life and Natural Sciences, Vol. 25, No. 1, pp 34-51. http://dx.doi.org/10.4314/ri.v25i1.3

Ubale, M.Y., Wee., T \& Martin, D. (2013). An Appraisal of Informal Sector and How it Flooded Residential Property Market in Nigeria. Journal of Business Administration and Education. Vol.4, No.1 pp 17-34

UNISDR.(2015). Making Development Sustainable: The future of Disaster Risk Management. Global Assessment Report on Disaster Risk Reduction. Geneva, Switzerland: United Nations Office for Disaster Risks Reduction(UNISDR).

Varley, A. (2009). Post colonising informality? (Re) Innovations and inventions: Latin America. Confronts $21^{\text {st }}$ Century ( $45^{\text {th }}$ Annual Conference of the Society for Latin American Studies: Leeds

Watson, V.(2009). 'The planned city sweeps the poor away....'Urban planning and $21^{\text {st }}$ century urbanization, Progress in Planning,72(3), pp 151-193.10.1016/j.progress.2009.06.002

Watson, V. (2003). Conflicting Rationalities: Implications for Planning Theory and Ethics. Planning Theory and Practice, Vol.4, No. 4, pp 395-407. 10.1080/1464935032000146318

Wisner, B, Blaikie, P; Cannon, T and Davis, I (2004). At Risk: Natural Disasters People's Vulnerability and Disasters. London, Routledge

World Bank, (2009). Malawi: Economic Vulnerability and Disaster Risk Assessment, Draft final report, Vol. 1, Main report

WMO \& GWP. (2007). The role of land use planning in flood management: A tool for integrated flood management associated programme for flood management, document No. 12, Version 1 